\title{
PERSPECTIVAS EDUCATIVAS Y SOCIALES DEL DISCURSO BIOÉTICO
}

Este número de Acta Bioethica, cuyo tema central es la educación y la docencia en un sentido amplio, recoge aportaciones de muy diversa naturaleza. Es un ejemplo de la diversidad de discursos, intereses y motivaciones que alberga lo que llamamos "bioética", especialmente en el contexto latinoamericano. Nunca dejaremos de lamentar las oportunidades perdidas para establecer una disciplina intelectual seria, por influencia de algunos espíritus exaltados que han creído ver en esta palabra polisémica un refugio para sus aspiraciones políticas contingentes, para ganar adeptos para causas no muy transparentes y para despotricar contra formas de poder. Mejor servidas estarían tales causas, que pueden tener legitimidad, si no se usara el apelativo "bioética" para promoverlas. Lo único que ello ha producido es desconfianza sobre la real capacidad académica de nuestras comunidades latinoamericanos, para hacer realidad el programa dialógico y tolerante que los pioneros quisieron implantar cuando hablaban de un "puente hacia el futuro" (Potter) o de un "imperativo bioético" (Jahr) que debería armonizar los esfuerzos en pro de la vida, la humana y la no humana.

La enseñanza de la bioética adopta, ciertamente, muchas formas. Primero, debe responderse a la pregunta de si tal enseñanza es necesaria. Vana y ociosa según algunos, irresponsable según otros, da pábulo a discusiones interminables sobre medios. Se aboga por presentaciones de casos, se insiste en textos, se recuerda el valor de los ejemplos, se defiende la formación filosófica elemental. Todos ellos son medios. Pero el fin de enseñar bioética parece ser, aunque no siempre se diga, la adquisición de un modo de raciocinio, de una forma de dialogar, y de habilidades y destrezas que permitan hacer realidad esa suerte de ideario de democrática armonía que quizá sea la característica de una praxis comunicativa cabal. Aquella en que los interlocutores se reconocen y respetan como tales. Y en que, como decía Gadamer, se acepta que los otros pueden, de buena fe, concebir ideas y propuestas distintas de las propias.

Es difícil aceptarlo, pero aún en sus formas vociferantes y extremas, esta bioética combativa, tercermundista, anti-capitalismo, anti-imperialismo, anti-casi todo, no ha producido idea alguna que valga la pena recapitular. Esto de intervenir, de superar las desigualdades, de combatir a ideologías liberales, fascistas o simplemente distintas es pintoresco y, en cierta medida, obliga a quienes deben trabajar en serio a desviar atención y esfuerzo a sacar del plano belicoso muchas afirmaciones en extremo triviales. Si no se tratara de hacerlas pasar por reflexiones, serían materia de broma o del iluminismo sectario de tanto grupo que cree haber descubierto las causas de la pobreza, la malignidad de las conspiraciones de la industria o la perversa conducta de gobiernos poderosos, y hasta podría justificar análisis. Pero al banalizar estas serias condiciones de la modernidad y hacer de ellas justificativo de agresiones y estridencias, nos dejan, no donde empezamos a dialogar, sino muy atrás en la vía de la convivencia.

Es difícil no sustraerse a la fácil denuncia, a acopiar argumentos sobre perversas prácticas, a reclamar contra el poder económico de grupos y países. Muchos de los que tal hacen no trepidan en aceptar sus beneficios. Es muy cómodo denunciar cuando se puede hacerlo desde la comodidad de un hotel financiado por aquellos a quienes se denuncia. La consecuencia exigiría que tales denunciantes nunca aceptaran invitaciones pagadas a congresos, subsidios de las instituciones que atacan o tan siquiera contactos con quienes las representan. Los estándares dobles suelen ser de regla.

En la comunidad bioética latinoamericana, si algo así pudiera describirse, no imperan siempre prácticas transparentes ni campea en todas partes la idoneidad o la honestidad. Como en todo grupo humano, hay conflictos. Muchas veces, prácticas denunciadas por los mismos que las practican, vienen avaladas por su amplia difusión. Presenciamos conflictos de interés, plagio, descalificaciones ocultas en la revisión de proyectos y publicaciones. Una ética de la bioética nos viene faltando hace ya tiempo. 
Lo dijimos en más de una ocasión. Lo observamos. Lo padecimos. Queda solamente esperar que la obtención de un necesario equilibrio sea materia de madurez y de tiempo.

Pero, entretanto, confiando que la evolución será positiva, repitamos una suerte de ideario. Confiamos que foros abiertos - como la revista Acta Bioethica - no renuncien a la crítica. Pero también confiamos que la preocupación bioética dejará de ser pretexto para decir todo lo que se le ocurre a iluminados que creen desempeñar el papel de salvadores de la humanidad. Las discrepancias son buenas cuando la tolerancia no es solo gesto sino también convicción. Una capacidad de comprender las dificultades inherentes a la vida social es requisito para la correcta valoración de las diferencias. Y, finalmente, reconocer los propios intereses - así sean estos muy mezquinos- es la garantía, o al menos la promesa, de un diálogo fructífero.

Las contribuciones de esta edición han sido, como es habitual, examinadas por pares evaluadores. Esta práctica pertenece a los rituales consagrados de la edición científica y quienes han asumido esta tarea deben ser reconocidos como piezas fundamentales del proceso. Acta Bioethica, por ser trilingüe, demanda contribuciones de muchos expertos, si bien debe reconocerse que no todos son igualmente diligentes. Sería de desear que reflexionáramos más en esta práctica, toda vez que — como ya advertíamos más arriba - el anonimato de los evaluadores puede a veces ser fuente de problemas. Nada impide, por ejemplo, que un evaluador celoso de su propio trabajo deseche un manuscrito que no lo cita. $\mathrm{O}$, como también hemos comprobado (pero no en esta revista), que buenas ideas sean usadas sin citar la fuente, pues han sido recibidas en un manuscrito sujeto a revisión. Un catálogo de las malas prácticas posibles sería instructivo. Recientemente, una revista internacional en la que actúo como revisor detectó que algunos autores crean - y sugieren — evaluadores inexistentes, aumentando de ese modo unas "sugerencias" cuya finalidad es evidente. Quede esta temática para un análisis ético de la función del evaluador, que si bien no ha sido descuidada en las publicaciones importantes, queda todavía librada a la conciencia individual. Especialmente en temas contenciosos o difíciles, que conllevan opinión, sería quizá oportuno introducir la práctica de la evaluación abierta, esto es, sin anonimato. También puede optarse por publicar los comentarios y permitir debate. Los tiempos de publicación hacen esto menos factible pero es sin duda una opción interesante.

Los tiempos de publicación son quizá menos relevantes cuando no media obtención de datos empíricos y hacen difícil respuestas y contrarrespuestas. Acta Bioethica, desde que ha alcanzado la dignidad de la indexación en bases de datos internacionales, recibe muchos manuscritos no solicitados y no es infrecuente la queja de autores que ven dilatada la espera por su publicación. Seguimos con atención estos desarrollos y nos complace saber que se prefiera la respetabilidad de los retrasos académicos a la celeridad de la publicación. Se observa en estos últimos tiempos la extraordinaria diversidad de temas que conforman lo que nuestros lectores consideran parte de lo bioético. Este número tiene, por ejemplo, muchos artículos que integran la sección miscelánea, si bien mantenemos la idea del epítome temático que ha caracterizado a nuestra revista desde sus comienzos.

Como es habitual, incluimos recensiones de libros y noticia de publicaciones recientes.

Fernando Lolas Stepke 